\title{
Eğitim Yöneticilerinin Yaşam Boyu Öğrenme Eğilimleri ile Bireysel Yenilikçilik Düzeylerinin İncelenmesi ${ }^{1}$
}

\begin{tabular}{|c|c|c|c|}
\hline $\begin{array}{l}\text { MAKALE TÜRÜ } \\
\text { Araştırma Makalesi }\end{array}$ & $\begin{array}{c}\text { Başvuru Tarihi } \\
02.01 .2018 \\
\end{array}$ & $\begin{array}{c}\text { Kabul Tarihi } \\
15.03 .2018 \\
\end{array}$ & $\begin{array}{c}\text { Erken Görünüm Tarihi } \\
16.03 .2018 \\
\end{array}$ \\
\hline \multicolumn{4}{|c|}{$\begin{array}{c}\text { Ramazan Yılmaz iD } \\
\text { Bartın Üniversitesi }\end{array}$} \\
\hline & $\begin{array}{l}\text { Yaşar Mu } \\
\text { Milli Eğ }\end{array}$ & $\begin{array}{l}\text { Beşkaya iD } \\
\text { Bakanlığg }\end{array}$ & \\
\hline
\end{tabular}

Öz

$\mathrm{Bu}$ araştırmanın amacı; eğitim yöneticilerinin yaşam boyu öğrenme eğilimleri ile bireysel yenilikçilik düzeylerini çeşitli değişkenlere (cinsiyet, yöneticilik deneyimi, yaş ve eğitim düzeyi) göre incelemek ve eğitim yöneticilerinin bireysel yenilikçilik düzeyleri ile yaşam boyu öğrenme eğilimleri arasındaki ilișkiyi belirlemektir. Araştırmada bu amaçla tarama yöntemi kullanılmıştır. Araştırmanın katılımcılarını 2015-2016 eğitim öğretim yılında Bartın ilinde görev yapan ve araștırmaya gönüllü olarak katılan 164 eğitim yöneticisi olușturmaktadır. Araştırma verileri araştırmacı tarafından geliştirilen anket, yaşam boyu öğrenme eğilimleri ölçeği ve bireysel yenilikçilik ölçeği ile elde edilmiştir. Araştırma sonucunda; eğitim yöneticilerinin yaşam boyu öğrenme eğilimleri ile bireysel yenilikçilik düzeyleri arasında pozitif yönde, orta düzeyde ve manidar bir ilişkinin olduğu sonucuna ulaşılmıştır. Araştırmadan elde edilen bulgular doğrultusunda araştırmacılara, uygulayıcılara ve karar vericilere çeşitli önerilerde bulunulmuştur.

Anahtar sözcükler: Eğitim yöneticileri, yaşam boyu öğrenme eğilimi, bireysel yenilikçilik

\footnotetext{
${ }^{1}$ Bu çalışma Bartın Üniversitesi Bilimsel Araştırmalar Proje Birimi tarafından desteklenmiştir (Proje No: 2016-SOS-CY-006).

${ }^{2}$ Sorumlu Yazar: Yrd. Doç. Dr., Eğitim Fakültesi, Bilgisayar ve Öğretim Teknolojileri Eğitimi Bölümü, Eposta: ramazanyilmaz067@gmail.com; https://orcid.org/0000-0002-2041-1750

${ }_{3}^{3}$ Öğretmen, E-posta: beskaya79@hotmail.com; https://orcid.org/0000-0002-8738-8372
} 
İçinde bulunduğumuz bilgi çağında, her alanda değișim ve yenilenme süreklilik göstermekte, toplumu oluşturan bireylerin bu sürece duyarsız kalması neredeyse olanaksız olarak görülmektedir. Bireylerin yaşamının her alanında sürekli karşı karşıya kalacakları bu durumlara uyum sağlayıp başarılı olabilmeleri de küçük yaşlardan itibaren kazanmaları gereken beceri ve yeteneklerle doğru orantılı olacaktır. Toplumu oluşturan bireylere bilgi çağının gereklilikleri olan değişim ve yeniliklere ayak uydurabilme becerilerinin kazandırılmasında ise okulların önemi büyüktür. Okullarda eğitim öğretim sürecine devam eden bireylere bilgi çağının gereklilikleri uygun öğrenme ortamları hazırlanarak kazandırılmalıdır. Hedeflenen bu sonuca ulaşabilmek, ayrıca yaşanan değişim ve yeniliklere ayak uydurabilmek için eğitim yöneticileri, sahip oldukları bilgi ve becerilerle eğitim öğretim ortamını düzenlemekte, dolayısıyla okulun geleceğini planlamaktadır. Aynı zamanda eğitim yöneticilerinin okuldaki değişim ve yenilikçilik çalışmalarını yürütmeleri zorunlu olmaktadır (Ağaoğlu, Altınkurt, Yılmaz ve Karaköse, 2012). Bu sebeple eğitim yöneticilerinin yaşam boyu öğrenme becerileri ve yenilikçilik yeterlikleri önem kazanmaktadır. Bu bağlamda 21. yüzyıl becerileri olarak da karşımıza çıkan; öz yönetim, öğrenmeyi öğrenme, inisiyatif ve girişimcilik, bilgiyi elde etme, karar verebilme ve dijital yeterlikler günümüz bireylerinde olması beklenilmektedir (Uzunboylu ve Hürsen, 2011).

Avrupa Birliği yaşam boyu öğrenmeyi, bireyin yaşamı boyunca katıldığı her türlü öğrenme etkinliklerinde kazandığı bilgi, beceri, ilgi ve yeterlikleri olarak tanımlamaktadır. Buna göre yaşam boyu öğrenmenin amacı, bireylerin içinde bulunduğumuz bilgi toplumunda yaşamlarını en iyi şekilde kontrol edebilmek amacıyla sosyal ve ekonomik yaşamın tüm evrelerine etkin katılımlarını sağlayarak bu toplumda yaşamlarını daha iyi kontrol edebilmelerine olanak sağlamaktır (Berberoğlu, 2010). Alanyazın incelendiğinde öğretmenler, öğretmen adayları, ortaöğretim öğrencileri gibi farklı örneklemlerdeki bireylerin yaşam boyu öğrenme yeterliklerini, tutumlarını, eğilimlerini, görüşlerini belirlemeye yönelik çeşitli araştırmalar olduğu görülmektedir. Ancak yöneticiler örneklemi üzerinde gerçekleştirilmiş araştırmaların sınırlı olduğu görülmektedir.

Diker Coşkun (2009) üniversite öğrencilerinin yaşam boyu öğrenme eğilimlerini belirlemeye yönelik araştırmasında; üniversiteye yerleşme puanı, gelir düzeyi, sınıf düzeyi, akademik başarı algı düzeylerine göre yaşam boyu öğrenme eğilimleri arasında manidar farklılık saptamıştır. Ayrıca; kız öğrencilerin erkeklerden, lisansüstü eğitime devam etmek isteyenlerin istemeyenlerden, iş yaşamında başarı beklentisi olanların olmayanlardan, Türkçe öğrenim dili ile eğitim görenlerin diğerlerinden ortalama puanlarının yüksek olduğu sonucuna ulaşmıştır. Genel olarak ise araştırmaya katılan üniversite öğrencilerinin yaşam boyu öğrenme eğilimlerinin düzeyini düşük olarak bulmuştur. Gencel (2013) öğretmen adaylarının yaşam boyu öğrenme yeterliklerini belirlemeye yönelik araştırmasında öğrenim görülen anabilim dalına göre manidar farklılık bulunduğu sonucuna ulaşmıştır. Ayrıca cinsiyet değişkeni açısından kadın öğretmen adaylarının, erkek adaylara göre puan ortalamalarının manidar derecede yüksek olduğu belirlenmiştir. Güçlü, Bostan ve Tabak (2013)'ın 
araştırmalarında, üniversite son sınıf öğrencilerinin yaşam boyu öğrenmeye orta düzeyde hazır oldukları belirlenmiştir. Karakuş (2013) ise meslek yüksekokulu öğrencilerinin yaşam boyu öğrenme yeterliklerinin saptanmasına yönelik araştırmasında, öğrenci yeterliklerinin iyi düzeyde olduğu, ayrıca öğrencilerin kayıtlı olduğu bölümlere göre aralarında manidar farklılığın olmadığı sonucuna ulaşmıştır. Öğrencilerin sınıf düzeyleri yükseldikçe doğru orantılı olarak yaşam boyu öğrenme yeterlik durumlarının da yükseldiği araştırmadan elde edilen bir diğer sonuçtur.

Bireysel yenilikçilik kavram olarak temelinde yenilik ve yenilikçilik kavramlarını içermektedir. Yenilikçilik kavramı yaşam boyu öğrenme becerileri (öz yönetim, öğrenmeyi öğrenme, inisiyatif ve girişimcilik, bilgiyi elde etme, karar verebilme ve dijital yeterlikler) içinde de yer almakta, birey veya kurumların değişim ve yeniliğe karşı tepkilerini kapsamaktadır. Yenilikçilik, yeni olana duyduğu istek ve yeniliği benimseme durumu ile davranışlarında yeniliğe karşı olumlu tepki verme süreci olarak da tanımlanabilir (Kılıçer, 2011). Alanyazın incelendiğinde öğretmenler, öğretmen adayları, ortaöğretim öğrencileri gibi farklı örneklemlerdeki bireylerin, bireysel yenilikçilik durumlarını incelemeye yönelik çeşitli araştırmalar olduğu görülmektedir. Ancak yöneticiler örneklemi üzerinde gerçekleştirilmiş araştırmaların sınırlı olduğu dikkat çekmektedir.

Beşkaya, Çelik ve Yılmaz (2015) tarafından gerçekleştirilen çalışmada sınıf öğretmenlerinin yenilikçiliğe ilişkin görüș ve yeterlikleri incelenmiştir. Araştırma kapsamında elde edilen bulgulara göre eğitim yöneticilerinin, bireysel yenilikçilik ve değişime karşı engeller oluşturduğu, okul ve kurum kültürünün yeniliğe ayak uydurmasında ise eksiklikler oluşturduğu yönündedir. Ancak eğitim yöneticilerinden beklenen ise çalışma ortamlarında öğretmen, öğrenci, veli ve diğer çevre paydaşlarının yaşam boyu öğrenme becerilerine ve bireysel yenilikçiliğe sahip olabilmesi noktasında okullarda uygun koşulların oluşturulması, öğrenci ve öğretmenlere gerekli desteğin sağlanmasıdır. Lope Pihie, Bagheri ve Asimiran (2014) okul yöneticiler girișimci liderlik uygulamaları ve yenilikçi davranışlarını öğretmen bakış açısıyla değerlendirmeye yönelik bir araştırma gerçekleştirmiştir. Araştırmaya göre öğretmenler, okul müdürlerinin okuldaki yenilikçi uygulamalarının, yönetim becerileri ve yöneticilerin eğitimine bağlı olduğunu belirtmektedir. Çetin (2009) işletmelerdeki liderlik anlayışının yenilikçilik eğilimlerine etkisini incelemek üzere gerçekleştirdiği araştırmasında, yöneticilerin liderlik türü anlayışlarının yenilikçilik eğilimlerine olumlu bir etkisinin bulunduğu görülmüştür. Yenilikçilik eğilimlerinin yaş ilerledikçe azaldığ 1 görülürken, cinsiyetin herhangi bir farklılık oluşturmadığ 1 görülmüştür. Bingöl (2006) işletme sahibi ya da yöneticileri üzerinde, bilişim teknolojilerinin üretim, sanayi ve işletmelerde kullanımı ve yenilikçilik arasındaki ilişkiyi araştırdığı çalışmasında, işletmelerin bilgisayar sahiplik oranı ve üretim sürecinde bilişim sistemlerinin kullanımı ile yenilikçilik arasında doğru yönlü bir ilişkinin bulunduğu belirlenmiştir. Scott ve Bruce (1994) bir araştırma ve geliştirme şirketinin çalışanları üzerinde yaptığı araştırmalarında liderliğin, grup bağlantılarının ve sorun çözme sitilinin, yenilikçi davranışı doğrudan veya dolaylı olarak yenilik iklimi algıları aracılığı ile bireysel yenilikçilik tutumunu etkilemekte olduğunu ortaya 
çıkarmışlardır. Ayrıca lider-üye etkileşiminin yenilikçi davranış üzerinde doğrudan ve dolaylı etkilerinin bulunduğu belirlenmiştir. McGeown (1980)'un öğretmenler üzerine yaptığı araştırmada, öğretmenlerin yenilikçilik durumları üzerinde, öğretmenin çalsştğ̆1 kurumun yenilikçiliğe karşı olan tutumunun etkili olduğu araştırma sonucunda saptanmıştır.

Bireylerin yaşam boyu öğrenen ve bireysel yenilikçiliğe sahip olarak yetişmelerinde okulların önemli bir işlevi vardır. Özellikle erken yaşlarda öğrencilerin bu becerilere sahip olması beklenilmektedir. Okullarda her ne kadar bu becerilerin kazandırılmasında öğretmenlere büyük sorumluluk düștüğü ifade edilmekle birlikte, öğretmenler kadar eğitim yöneticilerine de bu konuda sorumluluklar düşmektedir. Çünkü okulda bu yenilik kültürünün oluşmasında karar verici olarak temel sorumluluk yöneticilere düşmektedir. Eğitim yöneticilerinin okullarda uygulanacak yaşam boyu öğrenme etkinliklerinin, yenilik ve değişim hareketlerine ön ayak olabilmesi için öncelikle bu becerilere kendilerinin sahip olması önemlidir. Bu nedenle eğitim yöneticilerinin yaşam boyu öğrenme eğilimlerini ve bireysel yenilikçilik durumlarını belirlemek gerekmektedir. Alanyazın incelendiğinde çeşitli sektörlerde çalışan yöneticilerin, öğrencilerin ve öğretmenlerin yaşam boyu öğrenme eğilimleri ile bireysel yenilikçiliklerini inceleyen çeşitli araştırmalar olduğu görülmekle birlikte, eğitim yöneticilerinin yaşam boyu öğrenme eğilimleri ile bireysel yenilikçilik düzeylerini araştıran çalışmalara gereksinim duyulduğu dikkati çekmektedir. Bu nedenle günümüz eğitim yöneticisi atama sisteminde yaşanan değişimlerle birlikte, mevcut eğitim yöneticilerinin yaşam boyu öğrenme eğilimlerinin ve bireysel yenilikçilik düzeylerinin belirlenmesi, bu değişkenler üzerinde manidar bir etki gösteren değişkenlerin tespiti, okullarda gerçekleştirilecek yaşam boyu öğrenme ve yenilikçilik etkinlikleri açısından önemlidir. Ayrıca yaşam boyu öğrenme ve bireysel yenilikçilik ile ilgili alanyazın göz önünde bulundurulduğunda cinsiyet, eğitim düzeyi, yaş, mesleki kıdem gibi değişkenler açısından üniversite öğrencileri, öğretmenler gibi farklı örneklemler üzerinde gerçekleştirilen araştırmalardan elde edilen sonuçlar olmakla birlikte, eğitim yöneticileri açısından sonuçların nasıl olacağı belirsiz bir durumdur. Dolayısıyla bu değişkenlerin eğitim yöneticilerinin yaşam boyu öğrenme eğilimleri ile bireysel yenilikçilik düzeyleri üzerinde manidar bir fark oluşturup oluşturmayacağı araştırılması gereken bir noktadır. Bu bağlamda gerçekleştirilen bu araştırmanın amacı eğitim yöneticilerinin yaşam boyu öğrenme eğilimlerini ve bireysel yenilikçilik düzeylerini belirlemek, aralarındaki ilişkiyi incelemek ve bu özelliklerinin çeşitli değişkenler açısından farklılık gösterip göstermediğini belirlemektir. Araştırmanın genel amacından hareketle aşağıdaki sorulara yanıt aranmıştır:

1. Eğitim yöneticilerinin yaşam boyu öğrenme eğilimleri ne düzeydedir?

2. Eğitim yöneticilerinin bireysel yenilikçilik düzeyleri nedir?

3. Eğitim yöneticilerinin yaşam boyu öğrenme eğilimleri ile bireysel yenilikçilik düzeyleri arasında manidar bir ilişki var mıdır? 
4. Eğitim yöneticilerinin yaşam boyu öğrenme eğilimleri ile bireysel yenilikçilik düzeyleri cinsiyete göre manidar bir fark göstermekte midir?

5. Eğitim yöneticilerinin yaşam boyu öğrenme eğilimleri ile bireysel yenilikçilik düzeyleri yöneticilik deneyimine göre manidar bir fark göstermekte midir?

6. Eğitim yöneticilerinin yaşam boyu öğrenme eğilimleri ile bireysel yenilikçilik düzeyleri yaşa göre manidar bir fark göstermekte midir?

7. Eğitim yöneticilerinin yaşam boyu öğrenme eğilimleri ile bireysel yenilikçilik düzeyleri eğitim düzeyine göre manidar bir fark göstermekte midir?

\section{Yöntem}

Bu bölümde araştırmanın modeli, katılımcıları, veri toplama araçları ve verilerin analizine ilişkin bilgilere yer verilmiştir.

\section{Araştırma Modeli}

$\mathrm{Bu}$ araştırmada; eğitim yöneticilerinin yaşam boyu öğrenme eğilimleri ile bireysel yenilikçilik düzeylerinin belirlenmesi ve yaşam boyu öğrenme eğilimleri ile bireysel yenilikçilik düzeyleri arasındaki ilişkinin incelenmesi amaçlanmıştır. Bu amaçla kullanılan araştırma deseni, mevcut durumu ortaya koymak için kullanılan tarama modellerinden "ilişkisel tarama" modelidir.

\section{Katılımcılar}

Araştırmanın evrenini, 2015-2016 öğretim yılında Bartın ilinde, Bartın İl Milli Eğitim Müdürlüğü'ne bağlı devlet okullarında görev yapan eğitim yöneticileri oluşturmaktadır. Bu kapsamda Bartın ilinde görev yapan İl Milli Eğitim müdürü, müdür yardımcıları, şube müdürleri ile okul müdür ve müdür yardımcıları araştırmaya dâhil edilmiştir. Buna göre araştırmanın evrenini Bartın ili eğitim yöneticisi norm kadrolu 271 katılımcı oluşturmaktadır. Araştırmaya katılımda gönüllülük esas alınmıştır. Gönüllülük esasından kaynaklanan ulaşılabilir örneklem durumu dikkate alınarak araştırma, veri toplama araçlarını gönüllü olarak yanıtlayan 164 eğitim yöneticisi ile gerçekleştirilmiştir. Araştırma kapsamındaki eğitim yöneticilerinin demografik özellikleri Tablo 1'de sunulmuştur.

Tablo 1.

Araştırmaya Katılan Eğitim Yöneticilerinin Demografik Özellikleri

\begin{tabular}{lccc}
\hline Değişken & Grup & $\mathbf{N}$ & $\mathbf{\%}$ \\
\hline \multirow{2}{*}{ Cinsiyet } & Kadın & 26 & 15.86 \\
& Erkek & 138 & 84.14 \\
\hline Yöneticilik & 1-5 y1l aras1 & 71 & 43.29 \\
Deneyimi & 6-10 y1l aras1 & 43 & 26.22 \\
\hline
\end{tabular}


Tablo 1. (devam ediyor)

\begin{tabular}{lccc}
\hline & 11-15 y1l arası & 28 & 17.07 \\
& $16-20$ y1l arası & 14 & 8.54 \\
21 y1l ve üzeri & 8 & 4.88 \\
\hline \multirow{4}{*}{ Yaş } & 25-29 yaş arası & 2 & 1.22 \\
& 30-34 yaş arası & 17 & 10.37 \\
& 35-39 yaş arası & 45 & 27.44 \\
& 40-44 yaş arası & 61 & 37.20 \\
& 45-49 yaş arası & 17 & 10.37 \\
& 50-54 yas aras1 & 17 & 10.37 \\
Eğitim Düzeyi & 55 ve üstü & 5 & 3.05 \\
\hline
\end{tabular}

Tablo 1'de görüldüğü üzere araştırmaya katılan eğitim yöneticilerinin çoğunluğunun erkek olduğu, çoğunluğunun 1-5 yıl arasında yöneticilik deneyimine sahip olduğu, çoğunluğunun 40-44 yaş arasında olduğu ve büyük çoğunluğunun lisans düzeyinde eğitime sahip olduğu görülmektedir.

\section{Veri Toplama Araçları}

Araştırmada verilerin toplanmasında; araştırmacı tarafından geliştirilen ve katılımcılarla ilgili çeşitli demografik bilgileri elde etmek amacıyla kullanılan bilgi formu, katılımcıların yaşam boyu öğrenme eğilimlerini belirlemek amacıyla kullanılan "Yaşam Boyu Öğrenme Eğilimleri Ölçeği" ve katılımcıların bireysel yenilikçilik profilini belirlemek amacıyla kullanılan "Bireysel Yenilikçilik Ölçeği" kullanılmıştır.

Eğitim yöneticilerinin yaşam boyu öğrenme eğilimlerini saptamak amacıyla "Yaşam Boyu Öğrenme Eğilimlerini Belirleme Ölçeği” kullanılmıştır. Diker Çoşkun ve Demirel (2012) tarafından üniversite öğrencileri üzerinde geliştirilen ölçek 27 maddeli ve dört faktörlü bir yapıya sahiptir. Ölçek maddelerine ilişkin yanıtlara "Hiç Uymuyor", "Kısmen Uymuyor", "Çok Az Uymuyor", "Çok Az Uyuyor", "Kısmen Uyuyor", "Çok Uyuyor" olarak yedili likert tipli derecelendirme yapılmıştır. Ölçeğin birinci faktörü "Güdülenme" boyutunu (6 madde), ikinci faktörü "Sebat" boyutunu (6 madde), üçüncü faktörü "Öğrenmeyi Düzenlemede Yoksunluk" boyutunu (6 madde), dördüncü faktörü ise "Merak Yoksunluğu" boyutunu (9 madde) açıklamaktadır. Ölçeğin "Güdülenme" ve "Sebat" boyutları olumlu maddelerden, "Öğrenmeyi Düzenlemede Yoksunluk" ve "Merak Yoksunluğu" boyutları da olumsuz maddelerden oluşmaktadır. Araştırmacılar tarafından ölçeğin tamamı için hesaplanan güvenirlik değeri .89 olarak bulunmuştur. Yaşam boyu öğrenme eğilimleri ölçeğinden alınabilecek en düşük puan 27, en yüksek puan ise 162' dir (Diker Çoşkun ve Demirel, 2012). Ölçekten alınan puanın yüksek olması katılımcıların yaşam boyu öğrenme eğilimlerinin yüksek olduğunu göstermektedir. Bu araştırma için ölçeğin Cronbach alfa iç tutarlılık katsayısı yeniden hesaplanmış ve .94 olarak bulunmuștur. Ölçeğin alt 
boyutları için yeniden hesaplanan güvenirlik değerleri ise sırasıyla; $.82, .88, .84$ ve .79 olarak bulunmuştur.

Eğitim yöneticilerinin bireysel yenilikçilik düzeylerini tespit etmek amaciyla çalışma kapsamında "Bireysel Yenilikçilik Ölçeği” kullanılmıştır. Hurt, Joseph ve Cook (1977) tarafından geliştirilen ardından Kılıçer ve Odabaşı (2010) tarafından Türk kültürüne uyarlanan ölçek 20 maddeli dört faktörlü yapıya sahiptir. Ölçeğin faktörleri; "Değişime Direnç", "Fikir Önderliği", "Deneyime Açıklı" ve "Risk Alma" şeklindedir. Ölçek maddelerine ilişkin yanıtlara "Kesinlikle Katıllyorum", "Katıllyorum", "Ortadayım", "Katılmıorum", "Kesinlikle Katılmıyorum" olarak beşli likert tipli derecelendirme yapılmıştır. Ölçeğin 12'si pozitif maddelerden $(1,2$, $3,5,8,9,11,12,14,16,18$ ve 19. maddeler ile), 8 madde ise negatif maddelerden (4, $6,7,10,13,15,17$ ve 20 . maddeler) oluşmaktadır. Yenilikçilik puanı, ölçek aracılığı ile pozitif maddelerden alınan puan toplamından negatif maddelerden alınan puan toplamının çıkarılması ile oluşan farka 42 puan eklenerek hesaplanmaktadır. Ölçekten alınabilecek en yüksek puan 94, en düşük puan 14'tür. Araştırmacılar tarafindan ölçeğin tamamı için hesaplanan güvenirlik değeri .82; alt faktörler için ise sırasılyla $.81, .73, .77$ ve .62 olarak hesaplanmıştır (K1lıçer ve Odabaş1, 2010). Bu araştırma için ölçeğin geneline ilişkin Cronbach alfa iç tutarlık katsayısı yeniden hesaplanmış ve .86 olduğu saptanmıştır. Ölçeğin alt boyutları için yeniden hesaplanan güvenirlik değerleri ise sırasıyla; $.84, .75, .82$ ve .72 olarak bulunmuş̧ur.

\section{Verilerin Analizi}

Araştırma kapsamında uygulanan ölçeklerin ilk bölümünü oluşturan bilgi formundaki katılımcılara ait demografik özelliklerin analizinde betimsel istatistikler kullanılmıştır. Yine yaşam boyu öğrenme eğilimleri ile bireysel yenilikçilik ölçeği ve bu ölçeklerin alt boyutlarının ortalamalarını ve standart sapmalarını belirlemek için betimsel istatistikler kullanılmıştır. Elde edilen verilerin normallik varsayımı testinde Kolmogorov-Smirnov normallik testi uygulanmıştır. Kolmogorov-Smirnov normallik testi sonucunda bireysel yenilikçilik ölçeği verilerinin normal dağıldığı, yaşam boyu öğrenme eğilimleri ölçeği verilerinin normal dağılım göstermediği saptanmıştır. Araştırma kapsamında ele alınan her bir değişken için (cinsiyet, yöneticilik deneyimi, yaş, eğitim düzeyi) yaşam boyu öğrenme eğilimi ölçeğinin normallik varsayımı sınanmış ve tüm değişkenler için verilerin normal dağılmadığı gözlenmiştir. Benzer şekilde, her bir değişken için (cinsiyet, yöneticilik deneyimi, yaş, eğitim düzeyi) bireysel yenilikçilik ölçeğinin normallik varsayımı sınanmış ve tüm değişkenler için verilerin normal dağıldığ 1 gözlenmiştir. Bu nedenle bireysel yenilikçilik ölçeği verilerinin analizinde parametrik testlerden yararlanılırken; yaşam boyu öğrenme eğilimleri ölçeği verilerinin analizinde parametrik olmayan testlerden yararlanılmıştır. Araştırmada manidarlık testlerinde .05 düzeyi esas alınmıştır.

Yaşam boyu öğrenme eğilimleri ölçeği verilerinin normal dağılım göstermemesi nedeniyle eğitim yöneticilerinin yaşam boyu öğrenme eğilimleri ile bireysel yenilikçilik düzeyleri arasındaki ilişkiyi belirlemede, iki ölçek arasındaki Spearman's rho korelasyon katsayısı hesaplanmıştır. Cinsiyet ve öğrenim düzeyi (lisans/yüksek 
lisans) değişkenine göre eğitim yöneticilerinin yaşam boyu öğrenme eğilimlerinde manidar farkların olup olmadığını ortaya koymak amacıyla Mann-Whitney U testi yapılmıştır. Cinsiyet ve öğrenim düzeyi (lisans/yüksek lisans) değişkenine göre eğitim yöneticilerinin bireysel yenilikçilik düzeylerinde manidar farkların olup olmadığını ortaya koymak amacıyla bağımsız örneklemler t-testi yapılmıştır. Yıl olarak yöneticilik deneyimi ve yaş değiş̧kenlerine göre eğitim yöneticilerinin yaşam boyu öğrenme eğilimleri arasındaki farkları belirlemek için ise Kruskal Wallis $\mathrm{H}$ testi yapılmıştır. Yıl olarak yöneticilik deneyimi ve yaş değişkenlerine göre eğitim yöneticilerinin bireysel yenilikçilik düzeyleri arasındaki farkları belirlemek amacıyla ilişkisiz örneklemler için tek faktörlü varyans analizi yapılmıştır.

\section{Bulgular}

Bu bölümde araştırmanın alt amaçları doğrultusunda gerçekleştirilen analizlere ilişkin bulgulara yer verilmiştir.

\section{Eğitim Yöneticilerinin Yaşam Boyu Öğrenme Eğilimlerine İlişkin Bulgular}

Araştırmanın alt amaçlarından birincisi olan "Eğitim yöneticilerinin yaşam boyu öğrenme eğilimleri hangi düzeydedir?” sorusuna yanıt aramak için yapılan analizler sonucu elde edilen yaşam boyu öğrenme eğilimleri betimsel istatistikleri ve alt boyutlara ait istatistikler Tablo 2 'de verilmiştir.

\section{Tablo 2 .}

Eğitim Yöneticilerinin Yaşam Boyu Öğrenme Eğilimlerine İlişkin Betimsel Istatistikler

\begin{tabular}{lccccc}
\hline $\begin{array}{l}\text { Yaşam Boyu Öğrenme Ĕ̆ilimi } \\
\text { Ölçeği ve Alt Boyutları }\end{array}$ & $\mathbf{n}$ & $\begin{array}{c}\text { En düşük } \\
\text { puan }\end{array}$ & $\begin{array}{c}\text { En yüksek } \\
\text { puan }\end{array}$ & $\overline{\boldsymbol{X}}$ & SS \\
\hline Motivasyon & 164 & 21.00 & 36.00 & 31.96 & 3.11 \\
Sebat & 164 & 10.00 & 36.00 & 28.04 & 4.81 \\
Düzenlemede Yoksunluk & 164 & 10.00 & 36.00 & 29.82 & 6.72 \\
Merak Yoksunluğu & 164 & 14.00 & 54.00 & 43.60 & 9.76 \\
Ölçek Toplamı & 164 & 88.00 & 162.00 & 133.42 & 18.27 \\
\hline
\end{tabular}

Tablo 2 incelediğinde eğitim yöneticilerinin yaşam boyu öğrenme eğilimi ölçeğinden alınan en düşük puanın (88.00), en yüksek puanın ise (162.00) olduğu, ölçek ortalamasının ( $\bar{X}=133.42)$ olduğu görülmektedir. Alt boyutlar için incelendiğinde; motivasyon alt boyutunun puan ortalamasının $(\bar{X}=31.95)$, sebat alt boyutunun puan ortalamasının $(\bar{X}=28.04)$, düzenlemede yoksunluk alt boyutunun puan ortalamasının $(\bar{X}=29.82)$, merak yoksunluğu alt boyutunun puan ortalamasının $(\bar{X}=43.59)$ olduğu görülmektedir.

\section{Eğitim Yöneticilerinin Bireysel Yenilikçilik Düzeylerine İlişkin Bulgular}

Araştırmanın alt amaçlarından ikincisi olan "Eğitim yöneticilerinin bireysel yenilikçilikleri hangi düzeydedir?” sorusuna yanıt aramak için yapılan analizler 
sonucu elde edilen bireysel yenilikçilik düzeyleri betimsel istatistikleri ve alt boyutlara ilişkin istatistikler Tablo 3'de verilmiştir.

Tablo 3.

Ĕ̈itim Yöneticilerinin Bireysel Yenilikçilik Düzeylerine İlişkin Betimsel İstatistikler

\begin{tabular}{lccccc}
\hline $\begin{array}{l}\text { Bireysel Yenilikçilik } \\
\text { Ölçeği ve Alt Boyutları }\end{array}$ & $\mathbf{n}$ & $\begin{array}{c}\text { En düşük } \\
\text { puan }\end{array}$ & $\begin{array}{c}\text { En yüksek } \\
\text { puan }\end{array}$ & $\overline{\boldsymbol{X}}$ & SS \\
\hline Direnç & 164 & 8.00 & 36.00 & 20.63 & 5.43 \\
Fikir Önderliği & 164 & 5.00 & 25.00 & 18.02 & 3.66 \\
Deneyime Açıklık & 164 & 5.00 & 25.00 & 18.91 & 3.50 \\
Risk Alma & 164 & 2.00 & 10.00 & 6.78 & 1.77 \\
Ölçek Toplamı & 164 & 22.00 & 92.00 & 65.07 & 10.85 \\
\hline
\end{tabular}

Tablo 3 incelediğinde araştırmaya katılan eğitim yöneticilerinin bireysel yenilikçilik ölçeği puan ortalamasının $(\bar{X}=65.07)$ olduğu, ölçekten alınan en düşük puanın 22, en yüksek puanın ise 92 olduğu görülmektedir. Alt boyutlar için incelendiğinde; direnç alt boyutunun puan ortalamasının $(\bar{X}=20.63)$, fikir önderliği alt boyutunun puan ortalamasının $(\bar{X}=18.01)$, deneyime açıklık alt boyutunun puan ortalamasının $(\bar{X}=18.90)$, risk alma alt boyutunun puan ortalamasının $(\bar{X}=6.78)$ olduğu görülmektedir.

\section{Eğitim Yöneticilerinin Yaşam Boyu Öğrenme Eğilimleri ile Bireysel Yenilikçilik Düzeyleri Arasındaki İlişkiye İlişkin Bulgular}

Araştırmanın üçüncü alt amacında "Eğitim yöneticilerinin yaşam boyu öğrenme eğilimleri ile bireysel yenilikçilik düzeyleri arasındaki ilişki ne düzeydedir?” sorusuna yanıt aramak için yapılan Spearman's rho korelasyon analizi sonucunda korelasyonu ortaya koyan bulgulara Tablo 4'te yer verilmiştir.

Tablo 4.

Ĕ̆itim Yöneticilerinin Yaşam Boyu Öğrenme Eğilimleri ile Bireysel Yenilikçilik Düzeyleri Arasındaki İlişki

\begin{tabular}{|c|c|c|c|c|c|c|}
\hline & & Direnç & $\begin{array}{c}\text { Fikir } \\
\text { Önderliği }\end{array}$ & $\begin{array}{c}\text { Deneyime } \\
\text { Açıklık }\end{array}$ & $\begin{array}{c}\text { Risk } \\
\text { Alma }\end{array}$ & $\begin{array}{c}\text { Bireysel } \\
\text { Yenilikçilik } \\
\text { Ölçeği Toplam }\end{array}$ \\
\hline \multirow{3}{*}{ Motivasyon } & $\mathrm{r}$ & -.116 & $.199^{*}$ & $.290^{* *}$ & $.187^{*}$ & $.251^{* * *}$ \\
\hline & $\mathrm{p}$ & .138 & .011 & .000 & .017 & .001 \\
\hline & $\mathrm{n}$ & 164 & 164 & 164 & 164 & 164 \\
\hline \multirow{3}{*}{ Sebat } & $\mathrm{r}$ & -.082 & $.347^{* *}$ & $.390^{* *}$ & $.311^{* *}$ & $.307^{* *}$ \\
\hline & $\mathrm{p}$ & .295 & .000 & .000 & .000 & .000 \\
\hline & $\mathrm{n}$ & 164 & 164 & 164 & 164 & 164 \\
\hline \multirow{3}{*}{$\begin{array}{l}\text { Düzenlemede } \\
\text { Yoksunluk }\end{array}$} & $\mathrm{r}$ & $-.175^{*}$ & .051 & .124 & .143 & $.227^{* *}$ \\
\hline & $\mathrm{p}$ & .025 & .515 & .114 & .069 & .003 \\
\hline & $\mathrm{n}$ & 164 & 164 & 164 & 164 & 164 \\
\hline
\end{tabular}


Tablo 4 (devam ediyor)

\begin{tabular}{lcccccc}
\hline \multirow{2}{*}{ Merak } & $\mathrm{r}$ & $-.200^{*}$ & $.192^{*}$ & $.248^{* *}$ & $.206^{* *}$ & $.316^{* *}$ \\
Yoksunluğu & $\mathrm{p}$ & .010 & .014 & .001 & .008 & .000 \\
& $\mathrm{n}$ & 164 & 164 & 164 & 164 & 164 \\
\hline Yaşam Boyu & $\mathrm{r}$ & $-.201^{* *}$ & $.236^{* *}$ & $.317^{* *}$ & $.254^{* *}$ & $.362^{* *}$ \\
Öğrenme & $\mathrm{p}$ & .010 & .002 & .000 & .001 & .000 \\
Eğilimi Ölçeği & $\mathrm{n}$ & 164 & 164 & 164 & 164 & 164 \\
Toplam & & & & & &
\end{tabular}

$* \mathrm{p}<.05 ; * * \mathrm{p}<.01$

Tablo 4 incelendiğinde, yaşam boyu öğrenme eğilimleri ile bireysel yenilikçilik düzeyleri arasında pozitif yönde, orta düzeyde ve $(r=.36 ; \mathrm{p}<.01)$ olduğundan manidar bir ilişkinin olduğu görülmektedir (Büyüköztürk, 2004). Ölçeklerin alt boyutları arasındaki ilişkilerden ise; merak yoksunluğu ve bireysel yenilikçilik $(r=.32 ; p<.01)$, sebat ve risk alma $(\mathrm{r}=.31 ; \mathrm{p}<.01)$, sebat ve deneyime açıklık $(\mathrm{r}=.39 ; \mathrm{p}<.01)$, sebat ve fikir önderliği $(\mathrm{r}=.35 ; \mathrm{p}<.01)$, deneyime açıklık ve yaşam boyu öğrenme eğilimi $(\mathrm{r}=.32 ; \mathrm{p}<.01)$ arasında orta düzeyde bir ilişkinin varlığından söz edilebilir (Büyüköztürk, 2004). Diğer alt boyutlar olan; düzenlemede yoksunluk ve direnç $(\mathrm{r}=.17 ; \mathrm{p}<.05)$, merak yoksunluğu ve direnç $(\mathrm{r}=.20 ; \mathrm{p}<.05)$, direnç ve yaşam boyu öğrenme eğilimi $(r=.20 ; p<.01)$, motivasyon ve fikir önderliği $(r=.20 ; p<.05)$, merak yoksunluğu ve fikir önderliği $(\mathrm{r}=.19 ; \mathrm{p}<.05)$, fikir önderliği ve yaşam boyu öğrenme eğilimi $(\mathrm{r}=.24 ; \mathrm{p}<.01)$, deneyime açıklık ve motivasyon $(\mathrm{r}=.29 ; \mathrm{p}<.01)$, deneyime açıklık ve merak yoksunluğu $(\mathrm{r}=.25 ; \mathrm{p}<.01)$, risk alma ve motivasyon $(\mathrm{r}=.19 ; \mathrm{p}<.01)$, risk alma ve merak yoksunluğu $(\mathrm{r}=.21 ; \mathrm{p}<.01)$, risk alma ve yaşam boyu öğrenme eğilimi $(\mathrm{r}=.25 ; \mathrm{p}<.01)$, motivasyon ve bireysel yenilikçilik $(\mathrm{r}=.25 ; \mathrm{p}<.01)$, düzenlemede yoksunluk ve bireysel yenilikçilik $(\mathrm{r}=.23 ; \mathrm{p}<.01)$ arasında ise düşük düzeyde bir ilişkinin olduğu görülmektedir (Büyüköztürk, 2004).

Cinsiyete Göre Eğitim Yöneticilerinin Yaşam Boyu Öğrenme Eğilimleri ile Bireysel Yenilikçilik Düzeylerine İlişkin Bulgular

Araştırmaya katılan eğitim yöneticilerinin cinsiyete göre yaşam boyu öğrenme eğilimlerine ait Mann Whitney-U testi sonuçları Tablo 5'te sunulmuştur.

Tablo 5 .

Ĕ̆itim Yöneticilerinin Yaşam Boyu Öğrenme Ĕ̆glimlerinin Cinsiyete Göre Analizi

\begin{tabular}{lcccc}
\hline Cinsiyet & n & Sıra Ortalaması & U & p \\
\hline Erkek & 138 & 77.87 & \multirow{2}{*}{1154.50} & .004 \\
\hline Kadın & 26 & 107.10 & & \\
\hline
\end{tabular}

Tablo 5 incelendiğinde eğitim yöneticilerinin cinsiyete göre yaşam boyu öğrenme eğilimleri manidar farklılık görülmektedir $(U=1154.50, p<.05)$. Araştırmaya katılan kadın ve erkek eğitim yöneticilerinden, erkek olanların sıra ortalaması 
77.87 iken, kadın eğitim yöneticilerinin sıra ortalamalarının 107.10 olduğu görülmektedir. Elde edilen bulgularda oluşan manidar farklılığın kadın eğitim yöneticilerinin yaşam boyu öğrenme eğilimlerinin erkek eğitim yöneticilerinden yüksek olmasından kaynaklandığı söylenebilir. Bir diğer deyişle kadın eğitim yöneticilerinin erkek eğitim yöneticilerine göre yaşam boyu öğrenme eğiliminin yüksek olduğu görülmüştür.

Araştırmaya katılan eğitim yöneticilerinin cinsiyete göre bireysel yenilikçilik düzeylerine ait t testi sonuçları Tablo 6'da sunulmuştur.

Tablo 6.

Eğitim Yöneticilerinin Bireysel Yenilikçilik Düzeylerinin Cinsiyete Göre Analizi

\begin{tabular}{lcccccc}
\hline Cinsiyet & $\mathbf{n}$ & $\overline{\boldsymbol{X}}$ & SS & sd & t & p \\
\hline Erkek & 138 & 64.71 & 11.12 & \multirow{2}{*}{162} & \multirow{2}{*}{.987} & .325 \\
\hline Kadin & 26 & 67.00 & 9.24 & & & \\
\hline
\end{tabular}

Tablo 6'da cinsiyete göre eğitim yöneticilerinin bireysel yenilikçilik puanları arasında manidar bir fark olup olmadığını ortaya çıkarmak amacıyla t-testi yapılmıştır. Test sonucunda gruplar arasında $\left(\mathrm{t}_{(162)}=.987 ; \mathrm{p}>.05\right)$ manidar bir farklılık olmadığ görülmüştür. Bir diğer ifadeyle bireysel yenilikçiliğin cinsiyete göre manidar olarak farklılaşmadığı anlaşılmaktadır.

Yöneticilik Deneyimine (Yıl Olarak) Göre Eğitim Yöneticilerinin Yaşam Boyu Öğrenme Eğilimleri ile Bireysel Yenilikçilik Düzeylerine İlişkin Bulgular

Araştırmaya katılan eğitim yöneticilerinin yöneticilik deneyimine göre yaşam boyu öğrenme eğilimlerinde manidar bir farkın olup olmadığını belirlemek için yapılan Kruskal Wallis H testi yapılmıştır. Test sonucu Tablo 7'de gösterilmektedir.

Tablo 7.

Ĕ̈itim Yöneticilerinin Yaşam Boyu Öğrenme Eğilimlerinin Yöneticilik Deneyimine Göre Kruskal Wallis H Test sonuçları

\begin{tabular}{lccccc}
\hline $\begin{array}{l}\text { Yöneticilik } \\
\text { Deneyimi }\end{array}$ & $\mathbf{n}$ & $\begin{array}{c}\text { Sira } \\
\text { Ortalaması }\end{array}$ & sd & $\mathbf{X}^{\mathbf{2}}$ & $\mathbf{p}$ \\
\hline 1-5 y1l arası & 71 & 90.77 & & & \\
6-10 y1l arası & 43 & 70.42 & 4 & 5.280 & .260 \\
$11-15$ y1l arası & 28 & 84.38 & & \\
16-20 y1l arası & 14 & 76.39 & & \\
21 y1l ve üstü & 8 & 78.19 & & \\
\hline
\end{tabular}

Tablo 7 incelendiğinde; eğitim yöneticilerinin yöneticilik deneyimine göre yaşam boyu öğrenme eğilimleri $\left(\mathrm{X}_{(4)}^{2}=5.280, \mathrm{p}>.05\right)$ manidar bir fark olmadığ 
görülmüştür. Bir diğer ifadeyle yöneticilik deneyiminin yaşam boyu öğrenme eğilimine etkisinin olmadığı görülmüştür.

Araştırmaya katılan eğitim yöneticilerinin yöneticilik deneyimine göre bireysel yenilikçilik düzeyleri arasında manidar bir fark olup olmadığını belirlemek için yapılan Anova sonuçları Tablo 8'de gösterilmektedir.

Tablo 8 .

Eğitim Yöneticilerinin Bireysel Yenilikçilik Düzeylerinin Yöneticilik Deneyimine Göre Anova Sonuçları

\begin{tabular}{lccccccc}
\hline $\begin{array}{l}\text { Yöneticilik } \\
\text { Deneyimi }\end{array}$ & $\mathbf{n}$ & $\overline{\boldsymbol{X}}$ & $\mathbf{S S}$ & Sd & $\mathbf{F}$ & $\mathbf{p}$ & $\begin{array}{l}\text { Manidar } \\
\text { Farklılık }\end{array}$ \\
\hline 1-5 y1l aras1 & 71 & 61.97 & 11.51 & & & & \\
6-10 y1l aras1 & 43 & 66.07 & 8.53 & 4 & & & $1-5$ y1l aras1 ile \\
11-15 y1l arası & 28 & 67.68 & 9.64 & 159 & 3.393 & .011 & 21 y1l ve üstü \\
16-20 y1l arası & 14 & 68.21 & 11.78 & 163 & & & \\
21 y1l ve üstü & 8 & 72.63 & 12.21 & & & & \\
\hline
\end{tabular}

Tablo 8 incelendiğinde yöneticilik deneyiminin, bireysel yenilikçilik düzeyi değiş̧kenine göre manidar farklılık gösterdiği görülmektedir $\left(\mathrm{F}_{(4,159)}=3.393 ; \mathrm{p}<.05\right)$. Test sonucunda bu farkl1lığın 1-5 yıl arası ile 21 yıl ve üstü yöneticilik tecrübesine sahip eğitim yöneticileri arasında olduğu anlaşılmıştır. Genel olarak değerlendirildiğinde araştırmaya katılan eğitim yöneticilerinin yöneticilik deneyimi arttıkça bireysel yenilikçilik puanlarının da arttığı görülmektedir. Bir diğer deyişle yöneticilikte deneyim arttıkça bireysel yenilikçilik düzeyinde artış olduğu görülmüştür.

\section{Yaşa Göre Eğitim Yöneticilerinin Yaşam Boyu Öğrenme Eğilimleri ile Bireysel} Yenilikçilik Düzeylerine İlişkin Bulgular

Araştırmaya katılan eğitim yöneticilerinin yaşa göre yaşam boyu öğrenme eğilimlerinde manidar bir farkın olup olmadığını belirlemek için yapılan Kruskal Wallis H testi yapılmıştır. Test sonucu Tablo 9'da gösterilmektedir.

Tablo 9.

Ĕgitim Yöneticilerinin Yaşam Boyu Öğrenme Ĕ̆ilimlerinin Yaşa Göre Kruskal Wallis HTest Sonuçlarl

\begin{tabular}{lccccc}
\hline Yaş Aralığı (Yıl) & $\mathbf{n}$ & Sıra Ortalaması & sd & $\mathbf{X}^{\mathbf{2}}$ & $\mathbf{p}$ \\
\hline 25-30 yaş arası & 2 & 83.00 & & & \\
30-35 yaş arası & 17 & 85.44 & & & \\
35-40 yaş arası & 45 & 85.60 & 6 & & \\
40-45 yaş arası & 61 & 88.27 & & \\
45-50 yaş arası & 17 & 65.76 & & \\
50-55 yaş arası & 17 & 70.35 & & \\
55 yaş ve üstü & 5 & 72.20 & & & \\
\hline
\end{tabular}


Tablo 9 incelendiğinde; eğitim yöneticilerinin yaşa göre yaşam boyu öğrenme eğilimlerinde, $\left(\mathrm{X}_{(6)}^{2}=4.620, \mathrm{p}>.05\right)$ manidar bir fark olmadığı görülmüştür. Bir diğer ifadeyle yaşın yaşam boyu öğrenme eğilimine etkisinin olmadığı anlaşılmaktadır.

Araştırmaya katılan eğitim yöneticilerinin yaşa göre bireysel yenilikçilik düzeyleri arasında manidar bir fark olup olmadığını belirlemek için yapılan Anova sonuçları Tablo 10'da gösterilmektedir.

Tablo 10.

Eğitim Yöneticilerinin Bireysel Yenilikçilik Düzeylerinin Yaşa Göre Anova Sonuçları

\begin{tabular}{lcccccc}
\hline Yaş Aralığı & $\mathbf{n}$ & $\overline{\boldsymbol{X}}$ & $\mathbf{S S}$ & $\mathbf{S d}$ & $\mathbf{F}$ & $\mathbf{p}$ \\
\hline 25-30 yaş arası & 2 & 67.50 & 17.68 & & & \\
30-35 yaş arası & 17 & 67.24 & 10.13 & & & \\
35-40 yaş arası & 45 & 63.09 & 10.97 & 6 & & \\
40-45 yaş arası & 61 & 66.00 & 9.41 & 157 & .499 & \\
45-50 yaş arası & 17 & 64.00 & 14.71 & 163 & & \\
50-55 yaş arası & 17 & 65.06 & 11.13 & & \\
55 yaş ve üstü & 5 & 67.00 & 14.53 & & & \\
\hline
\end{tabular}

Tablo 10 incelendiğinde araștırmaya katılan eğitim yöneticilerinin yaș aralığına göre bireysel yenilikçilik düzeyleri arasında manidar bir fark bulunmamıştır $\left(\mathrm{F}_{(6,157)}=\right.$ $.499 ;$ p >.05). Bir diğer ifadeyle yaş aralığının bireysel yenilikçiliğe etkisinin olmadığı görülmüştür.

Eğitim Düzeyine Göre Eğitim Yöneticilerinin Yaşam Boyu Öğrenme Eğilimleri ile Bireysel Yenilikçilik Düzeylerine İlişkin Bulgular

Araştırmaya katılan eğitim yöneticilerinin eğitim düzeyine göre yaşam boyu öğrenme eğilimlerine ait Mann Whitney-U testi sonuçları Tablo 11'de sunulmuştur.

Tablo 11

Ĕ̆itim Yöneticilerinin Yaşam Boyu Öğrenme Eğilimlerinin Eğitim Düzeyine Göre Analizi

\begin{tabular}{lccccccc}
\hline $\begin{array}{l}\text { Ĕ̈itim } \\
\text { Düzeyi }\end{array}$ & $\mathbf{n}$ & $\overline{\boldsymbol{X}}$ & $\mathbf{S S}$ & $\begin{array}{c}\text { Sıra } \\
\text { Ortalaması }\end{array}$ & $\begin{array}{c}\text { Suralar } \\
\text { Toplamı }\end{array}$ & $\mathbf{U}$ & $\mathbf{p}$ \\
\hline Lisans & 140 & 132.01 & 18.59 & 78.40 & 10976.50 & & \\
\cline { 1 - 1 } $\begin{array}{l}\text { Yüksek } \\
\text { Lisans }\end{array}$ & 24 & 141.67 & 13.92 & 106.40 & 2553.50 & 1106.50 & .008 \\
\hline
\end{tabular}

Tablo 11 incelendiğinde, eğitim yöneticilerinin eğitim düzeyine göre yaşam boyu öğrenme eğilimlerinde manidar farklılık göstermektedir $(U=1106.50, \mathrm{p}<.05)$. Araştırmaya katılan lisans ve yüksek lisans mezunu eğitim yöneticilerinden, lisans mezunu olanların yaşam boyu öğrenme toplam puanı $\bar{X}=132.00$ iken, yüksek lisans 
mezunu eğitim yöneticilerinin yaşam boyu öğrenme toplam puanının $\bar{X}=141.66$ olduğu görülmektedir. Elde edilen bulgularda oluşan manidar farklılığın yüksek lisans mezunu eğitim yöneticilerinin yaşam boyu öğrenme eğilimlerinin lisans mezunu eğitim yöneticilerinden yüksek olmasından kaynaklandığı söylenebilir. Bir diğer deyişle eğitim yöneticilerinin eğitim düzeyi arttıkça yaşam boyu öğrenme eğiliminin de arttığı görülmüştür.

Araştırmaya katılan eğitim yöneticilerinin eğitim düzeyine göre bireysel yenilikçilik düzeyleri ile ilgili t testi sonuçları Tablo 12'de sunulmuştur.

Tablo 12.

Ĕ̆itim Yöneticilerinin Bireysel Yenilikçilik Düzeylerinin Eğitim Düzeyine Göre Analizi

\begin{tabular}{|c|c|c|c|c|c|c|}
\hline $\begin{array}{l}\text { Eğitim } \\
\text { Düzeyi }\end{array}$ & n & $\bar{X}$ & SS & sd & $\mathbf{t}$ & $\mathbf{p}$ \\
\hline Lisans & 140 & 64.62 & 10.94 & \multirow{2}{*}{162} & \multirow{2}{*}{1.29} & \multirow{2}{*}{.199} \\
\hline Yüksek Lisans & 24 & 67.71 & 10.18 & & & \\
\hline
\end{tabular}

Tablo 12'de eğitim düzeylerine göre eğitim yöneticilerinin bireysel yenilikçilik puanları arasında manidar bir fark olup olmadığını ortaya çıkarmak amacıyla t-testi yapılmıştır. Araştırmaya katılan lisans mezunu eğitim yöneticilerinin bireysel yenilikçilik puan ortalaması $\bar{X}=64.62$, yüksek lisans mezunu eğitim yöneticilerinin bireysel yenilikçilik puan ortalamasının $\bar{X}=67.70$ olduğu görülmüştür. $\mathrm{Bu}$ farkın $\left(\mathrm{t}_{(162)}=1.290 ; \mathrm{p}>.05\right)$ manidar olmadığı görülmüştür. Bir diğer ifadeyle eğitimin düzeyinin bireysel yenilikçiliğe etkisi olmadığg görülmüştür.

\section{Tartışma ve Sonuç}

$\mathrm{Bu}$ araştırma kapsamında eğitim yöneticilerinin yaşam boyu öğrenme eğilimlerinin düzeyinin belirlenmesi amaçlanmış olup genel olarak eğitim yöneticilerinin yaşam boyu öğrenme eğilimlerinin yüksek olduğu sonucuna ulaşılmıştır. Bir diğer ifade ile araştırmanın katılımcıları olan eğitim yöneticilerinin yaşam boyu öğrenmeye yatkın oldukları, kişisel ve mesleki gelişimlerini geliştirmek için öğrenmeye açık oldukları söylenebilir. Eğitim yöneticilerinin yaşam boyu öğrenme eğilimlerinin yüksek bulunması okullarda uygulanacak yaşam boyu öğrenme etkinliklerinin planlanması, desteklenmesi, sürdürülebilirliğinin sağlanması, öğretmenlerin ve öğrencilerin katılımlarının teşvik edilmesi açısından eğitim yöneticilerinin rol model olabileceğine işaret etmektedir. Bu sonuç alanyazındaki sonuçlarla karşılaştırıldığında benzerliklerin ve farklılıkların olduğu görülmektedir. İlgili çalışmalar kapsamında öğretmenlerin yaşam boyu öğrenme eğilimlerinin belirlenmesine yönelik (Özçiftçi, 2014; Kılıç ve Ayvaz Tuncel, 2014; Ayra, 2015; Dündar, 2016) gerçekleştirilen araştırmalarda öğretmenlerin yaşam boyu öğrenme eğilimlerinin yüksek olduğu sonucuna ulaşılmıştır. Yine bu çalışmaları destekler nitelikte Karaduman (2015), üniversite öğrencilerinin yaşam boyu öğrenme 
eğilimlerinin yüksek olduğu sonucuna ulaşmıştır. Başka bir çalışmada Kılınç ve Yenen (2015) halk eğitim kursiyerlerinin yaşam boyu öğrenme eğilimlerinin yüksek olduğu sonucunu elde etmiştir. Erdoğan (2014), Ergün ve Özata (2016) tarafından yapılan araştırmalarda da öğretmen adaylarının yaşam boyu öğrenme eğilimlerinin yüksek olduğu saptanmıştır. Bu çalışmanın aksine; Tunca, Şahin Alkın ve Aydın (2015) öğretmen adaylarının, Diker Coşkun (2009) üniversite öğrencilerinin yaşam boyu öğrenme eğilimlerini düşük bulmuştur. Yaşam boyu öğrenme eğilimi düzeyinin belirlenmesine yönelik yapılan araştırmalarda çoğunlukla yaşam boyu öğrenme eğilimlerinin yüksek bulunduğu gözlenmekte olup yapılan çalışmalarda özellikle öğretmenler ve öğretmen adaylarının yaşam boyu öğrenme eğilimleri yüksek bulunmuştur.

Araştırmanın alt amacında eğitim yöneticilerinin yaşam boyu öğrenme eğilimlerinin cinsiyete göre farklılık gösterip göstermediği incelemiş ve sonuç olarak yaşam boyu öğrenme eğilimlerinin cinsiyete göre manidar farklılık gösterdiği ve bu farkın kadınlar lehine manidar olduğu görülmüştür. $\mathrm{Bu}$ sonuç alanyazınla karşılaştırıldığında elde edilen sonuçları destekler nitelikte yapılan birçok çalışmada da kadınların yaşam boyu öğrenme eğilimlerinin yüksek çıktığı görülmektedir. Ayra (2015), Özçiftçi (2014); Kılıç ve Tuncel Ayvaz (2014) tarafından gerçekleştirilen araştırmalarda kadın öğretmenlerin yaşam boyu öğrenme eğilimlerinin yüksek olduğu sonucuna ulaşılmıştır. Yine Karaduman (2015), Diker Coşkun (2009)'un üniversite öğrencileri üzerine yaptığı çalışmalarda kadınların yaşam boyu öğrenme eğilimlerinin daha yüksek olduğu sonucuna ulaşmışlardır. Kılınç ve Yenen (2015)'in halk eğitim kursiyerleri ile gerçekleştirdiği çalışmada kadın kursiyerlerin yaşam boyu öğrenme eğilimlerinin daha yüksek olduğu sonucuna ulaşmıştır. Erdoğan (2014) öğretmen adayları ile yaptığ eğilimlerinin daha yüksek olduğu saptanmıştır.

Araştırmanın alt amacında eğitim yöneticilerinin yaşam boyu öğrenme eğilimlerinin yöneticilik deneyimine (yöneticilik kıdem yılına) göre farklılık gösterip göstermediği incelemiş ve sonuç olarak yaşam boyu öğrenme eğilimlerinin yöneticilik deneyimine göre manidar farklılık göstermediği görülmüştür. Araştırmanın bir diğer alt amacında ise eğitim yöneticilerinin yaşam boyu öğrenme eğilimlerinin yaşa göre farklılık gösterip göstermediği incelemiş ve sonuç olarak yaşam boyu öğrenme eğilimlerinin yaşa göre manidar farkl1lık göstermediği görülmüştür. Alanyazın incelendiğinde, öğretmenlerin yaşam boyu öğrenme yeterlikleri düzeyini çeşitli değişkenler açısından incelediği araştırmasında, Şahin ve Arcagök (2014), mesleki kıdemi 31 yıl ve üzerinde olan öğretmenlerin yaşam boyu öğrenme yeterlikleri düzeyinin bütün alt boyutlarında daha düşük çıktığ 1 sonucuna ulaşmışlardır. Benzer bir şekilde öğretmenlerin mesleki tükenmişlik düzeylerini farklı değişkenlere göre inceleyen, Cemaloğlu ve Erdemoğlu Şahin (2007), öğretmenlerin yaşları ve tükenmişlik düzeyleri arasında manidar bir fark bulmuşlar ve öğretmenlerde ilerleyen yaşla beraber duyarsızlaşma ve duygusal tükenme düzeylerinin de arttığ sonucuna ulaşmışlardır. Elde edilen bu sonuçları da mesleki deneyimi fazla olan yaşlı öğretmenlerin genç öğretmenlere göre mesleklerini yaparken kendilerini daha fazla 
yorgun hissederek, mesleki performanslarının düşmesine, mesleki anlamda duyarsızlaşmalarına ve duygusal yıpranmalara neden olduğu yönünde açıklamışlardır.

Araştırmanın alt amacında eğitim yöneticilerinin yaşam boyu öğrenme eğilimlerinin eğitim düzeyine göre farklılık gösterip göstermediği incelemiş ve sonuç olarak yaşam boyu öğrenme eğilimlerinin eğitim düzeyine göre manidar farkl1lık gösterdiği ve bu farkın eğitim düzeyi fazla olanlar (yüksek lisans) lehine olduğu görülmüş̧ür. Bir diğer deyişle eğitim yöneticilerinin eğitim düzeyi arttıkça yaşam boyu öğrenme eğiliminin de arttığı görülmüştür.

Araştırmaya katılan eğitim yöneticilerinin bireysel yenilikçilik düzeyinin sorgulayıc1 kategoride olduğu görülmektedir. $\mathrm{Bu}$ sonuç alanyazınla karşılaştırıldığında alanyazındaki sonuçlarla benzerlikler ve farklılıklar olduğu görülmektedir. Son y1llarda eğitim sistemimizde teknolojik altyapı, olanaklar ve bilgiye erişimde kolaylıklar gibi birçok değişimin çok hızlı yaşamımıza girmesi, eğitim yöneticilerinin bu yenilikleri istenilen düzeyde uyum sağlayarak benimsemesine olanak sağlayamamış olabilir. Yine Rogers (1995) bireysel yenilikçilik düzeyinin sorgulayıcı kategorideki bireylerin, yeniliklere karşı tedbirli davranış sergilediklerini, yeniliği benimsemeden önce, onun üstün ve zayıf yönlerini değerlendirdiklerini belirtmektedir. Bu bağlamda araştırma kapsamındaki eğitim yöneticileri sorgulayıcı kategoride olduğundan, çok sık ve kısa zaman aralıklarında gerçekleșen yenilik ve değișime karșı tedbirli davrandıkları ve bir miktar direnç gösterdikleri söylenebilir. Alanyazında bireylerin yenilikçilik kategorilerine göre dağılımını inceleyen çoğu araştırmada da benzer sonuçlar görülmektedir (Kıllıçer, 2011; Kert ve Tekdal, 2012; Çuhadar, Bülbül ve Ilgaz, 2013; Köroğlu, 2014; Önen ve Koçak, 2014; Yılmaz Öztürk ve Summak, 2014).

Araştırmanın alt amacında eğitim yöneticilerinin bireysel yenilikçilik düzeylerinin cinsiyete göre farklılık gösterip göstermediği incelemiş ve sonuç olarak bireysel yenilikçilik düzeylerinin cinsiyete göre manidar farklılık göstermediği görülmüştür. Benzer sonuçlara, alanyazındaki çeşitli araştırmalarda rastlanmaktadır (Çuhadar, Bülbül ve Ilgaz, 2013; Kılıçer, 2011).

Araştırmanın alt amacında eğitim yöneticilerinin bireysel yenilikçilik düzeylerinin yöneticilik deneyimine göre farklılık gösterip göstermediği incelenmiş ve sonuç olarak bireysel yenilikçilik düzeylerinin yöneticilik deneyimine göre manidar farklılık gösterdiği ve bu farklılığın yöneticilik tecrübesi 1-5 yıl arasında olan eğitim yöneticilerinin lehine olduğu görülmektedir.

Araştırmanın alt amacında eğitim yöneticilerinin bireysel yenilikçilik düzeylerinin yaşa göre farklılık gösterip göstermediği incelemiş ve sonuç olarak bireysel yenilikçilik düzeylerinin yaşa göre manidar farklılık göstermediğ görülmüştür. Araştırmanın alt amacında eğitim yöneticilerinin bireysel yenilikçilik düzeylerinin eğitim düzeyine göre farkl1lık gösterip göstermediği incelenmiş ve sonuç olarak bireysel yenilikçilik düzeylerinin eğitim düzeyine göre manidar farkl1lık göstermediği görülmüştür. 
Araştırmaya katılan eğitim yöneticilerinin yaşam boyu öğrenme eğilimleri ile bireysel yenilikçilik düzeyleri arasında pozitif yönde, orta düzeyde ve manidar bir ilişki olduğu sonucuna ulaşılmıştır. Araştırma kapsamında eğitim yöneticilerinin yaşam boyu öğrenme eğilimleri yüksek çıkarken, bireysel yenilikçilik düzeylerinin orta düzeyde olduğu görülmektedir. Araştırma kapsamındaki eğitim yöneticileri sorgulayıcı kategoride olduğundan, çok sık ve kısa zaman aralıklarında gerçekleşen yenilik ve değişime karşı eğitim yöneticilerinin tedbirli davrandıkları ve bir miktar direnç gösterdikleri söylenebilir. Znidarsic ve Jereb (2011) araştırmalarında toplumların gelişim düzeyleri ile yaşam boyu öğrenme ve yenilikçiliğe yapılan yatırımlar arasında pozitif bir ilişki olduğu sonucuna ulaşmışlardır.

Araştırmadan elde edilen bulgular ışığında, eğitim yöneticilerinin yaşam boyu öğrenme eğilimleri ile bireysel yenilikçilik düzeylerini geliştirmeye ayrıca yeni yapılacak çalışmalara yönelik çeşitli öneriler verilebilir. Yapılan araştırmadan elde edilen bulgu ve sonuçlar 1şığında, eğitim yöneticilerinin saptanmasına ve var olan eğitim yöneticilerinde, yaşam boyu öğrenmeye ve bireysel yenilikçiliğe yönelik farkındalı̆̆ı arttırma çalışmaları yapılmalıdır. Eğitim yöneticilerine yapılan araştırma kapsamında elde edilen bulgularda eğitim düzeyi yükseldikçe yaşam boyu öğrenme eğiliminin de arttığı saptanmış, eğitim yöneticilerinin seçim ve atanmasında yüksek lisans ve doktora mezunu adaylara öncelik verilebilir. Eğitim yöneticisi olarak görev yapmakta olanlara da yüksek lisans ve doktora programlarını bitirme yönünde özendirme sağlanabilir. Yapılan araştırma kapsamında eğitim yöneticilerinin cinsiyet değişkeninde erkek yönetici sayısının kadın yönetici sayısından bir hayli fazla olduğu görülse de kadın yöneticilerin yaşam boyu öğrenme eğilimleri erkek yöneticilere göre daha yüksek çıkmıştır. Bu bağlamda ülkemizde genel anlamda sayıları az olan kadın yöneticilerin eğitim sisteminde görev almalarını özendirici önlemler alınmalıdır. Araştırma kapsamında yöneticilik deneyiminin bireysel yenilikçilik düzeyinde manidar bir fark oluşturduğu sonucuna dayanarak, eğitim kurumlarında yöneticilerin belirlenme ve seçiminde deneyim ölçütü dikkate alınmalıdır. Araştırma kapsamındaki eğitim yöneticilerinin çoğunluğunun "Sorgulayıcı" kategorisinde yer aldığ 1 düşünülürse, eğitim yöneticilerinin yeniliklere karşı olan olumsuz ve kuşkucu yaklaşımlarının incelenmesi önerilebilir. Eğitim kurumlarında öğretmen, öğrenci, veli ve kurumun farklı paydaşları ile sürekli iletişim ve etkileşim halinde olan eğitim yöneticilerinin kurum misyon ve vizyonunu düzenlemesi, ayrıca kurumsal başarıyı artırması için yaşam boyu öğrenme becerileri ve bireysel yenilikçilik farkındalıkları önemli konulardır. Bu nedenle özellikle Milli Eğitim Bakanlığ 1 tarafından eğitim yöneticilerinin ilgi, istek ve ihtiyaçları doğrultusunda yaşam boyu öğrenme ve yenilikçilik konularında hizmet içi eğitimler düzenlenmesi, eğitim yöneticilerinin katılımının sağlanması önerilebilir. Milli Eğitim Bakanlığı tarafından yenilik, yenilikçilik, yaşam boyu öğrenme, öğrenmeyi öğrenme vb. başlıklarda düzenlenmekte olan mesleki ve kişisel gelişim seminerlerine eğitim yöneticilerinin katılımları özendirilebilir. Eğitim yöneticilerinin kazanmış oldukları bilgi ve deneyimlerini okul içi ve okul dişı tüm paydaşlarla paylaşabilmeleri ve gerektiğinde rehberlik yapabilmeleri sağlanabilir. Eğitim yöneticilerinin yaşam boyu öğrenme 
eğilimleri ve bireysel yenilikçilik düzeylerini daha ayrıntılı saptanmasını sağlamak için nitel araştırmalar yapılabilir. Eğitim yöneticilerinin yaşam boyu öğrenme eğilimleri ile bireysel yenilikçilik düzeyleri üzerinde etkilerinin olabileceği düşünülen öğretmen, öğrenci, veli, aile vb. farklı paydaşlara yönelik çalışmalar yapılabilir. Farklı sosyolojiye sahip bölgeler ile bu bölgelerde seçilen okul ve kurumlardaki eğitim yöneticileri üzerinde çalışılıp bölgeler arasındaki farklılık ve benzerlikler ilişkisel olarak incelenebilir. Eğitim yöneticilerinin ve öğretmenlerin yaşam boyu öğrenme eğilimleri ve bireysel yenilikçilik düzeyleri üzerine kişisel, mesleki ve toplumsal düzeyde engelleme olarak karşılaştıkları durumların incelenebileceği nicel ve nitel araştırmalar yapılabilir. 


\section{Kaynakça}

Ağaoğlu, E., Altınkurt, Y., Yıılmaz, K. ve Karaköse, T. (2012). Okul yöneticilerinin yeterliklerine ilişkin okul yöneticilerinin ve öğretmenlerin görüşleri (Kütahya ili). Ĕgitim ve Bilim Dergisi, 37(164), 159-175.

Ayra, M. (2015). Öğretmenlerin yaşam boyu öğrenme eğilimlerinin mesleki öz yeterlik inançlart ile ilişkisi. Yüksek Lisans Tezi, Amasya Üniversitesi, Amasya.

Berberoğlu, B. (2010). Yaşam boyu öğrenme ile ilgili bilgi ve iletişim teknolojileri açısından Türkiye'nin Avrupa Birliği’ndeki konumu. Bilgi Ekonomisi ve Yönetimi Dergisi, 5(2), 113-126.

Beşkaya, M., Çelik, İ. ve Yılmaz, R. (2015). Sınıf öğretmenlerinin inovasyona ilişkin görüşlerinin incelenmesi. 14. Uluslararast Katılımlı Sınıf Öğretmenliği Ĕ̆itimi Sетроzуити, 21-23 Mayıs 2015, Bartın Üniversitesi, Bartın.

Bingöl, M. (2006). İşletmelerde biliş̧im teknolojileri ve yenilikçilik: Erzurum, Erzincan ve Bayburt'taki imalat işletmeleri üzerine bir araştırma. Yayınlanmamış Yüksek Lisans Tezi, Atatürk Üniversitesi, Erzurum.

Büyüköztürk, Ş. (2004). Sosyal bilimler için veri analizi el kitabı. Ankara: Pegem A Yayıncılık.

Cemaloğlu, N. ve Şahin, D. E. (2007). Öğretmenlerin mesleki tükenmişlik düzeylerinin farklı değișkenlere göre incelenmesi. Kastamonu Eğitim Dergisi, 15(2), 465-484.

Çetin, T. (2009). Tam serbesti tanıyan liderlik anlayışının orta kademe yöneticilerin yenilikçilik eğilimleri üzerindeki etkisi: Ege bölgesindeki mobilya işletmelerinde bir uygulama. Yayımlanmamış Yüksek Lisans Tezi, Dumlupınar Üniversitesi, Kütahya.

Çuhadar, C., Bülbül, T. ve Ilgaz, G. (2013). Öğretmen adaylarının bireysel yenilikçilik özellikleri ile teknopedagojik eğitim yeterlikleri arasındaki ilişkinin incelenmesi. Ilköğretim Online, 12(3), 797-807.

Diker Coşkun, Y. (2009). Üniversite öğrencilerinin yaşam boyu öğrenme eğilimlerinin bazı değişkenler açısından incelenmesi. Doktora Tezi, Hacettepe Üniversitesi, Ankara.

Diker Coşkun, Y. ve Demirel, M. (2012). Üniversite öğrencilerinin yaşam boyu öğrenme eğilimleri. Hacettepe Üniversitesi Eğitim Fakültesi Dergisi, 42, 108-120.

Dündar, H. (2016). Sını öğretmeni adaylarının yaşam boyu öğrenme eğilimlerinin incelenmesi. Yüksek Lisans Tezi, Atatürk Üniversitesi, Erzurum.

Erdoğan, D. G. (2014). Öğretmen adaylarının yaşam boyu ögrenme eğilimlerine etki eden faktörler. Doktora Tezi, Abant İzzet Baysal Üniversitesi, Bolu.

Gencel, İ., E. (2013). Öğretmen adaylarının yaşam boyu öğrenme yeterliklerine yönelik algıları. Eğitim ve Bilim, 38(170), 237-252.

Güçlü, S., Bostan, N. ve Tabak, R., S. (2013). Dumlupınar Üniversitesi hemșirelik bölümü son sınıf öğrencilerinin yaşam boyu öğrenme davranışlarının belirlenmesi. Kastamonu Eğitim Dergisi, 21(2), 459-468.

Karaduman, A. (2015). Üniversite ögrencilerinin yaşam boyu ögrenme eğilimleri ile özyeterlik algıları arasındaki ilişki. Yüksek Lisans Tezi, Bartın Üniversitesi, Bartın. 
Karakuş, C. (2013). Meslek yüksekokulu öğrencilerinin yaşam boyu öğrenme yeterlikleri. Eğitim ve Ö̆̆retim Araştırmaları Dergisi, 2(3), 26-35.

Kert, S. B. ve Tekdal, M. (2012). Comparison of individual innovativeness perception of students attending different education faculties. University of Gaziantep Journal of Social Sciences, 11(4), 1150-1161.

Kilınç, H. H. ve Yenen, E. T. (2015). Halk eğitim merkezi kursiyerlerinin yaşam boyu öğrenme eğilimleri. The Journal of Academic Social Science Studies, 35, 187-198.

K1lıçer, K. ve Odabaşı, H. F. (2010). Bireysel yenilikçilik ölçeği (BYÖ): Türkçeye uyarlama, geçerlik ve güvenirlik çalışması. Hacettepe Üniversitesi Eğitim Fakültesi Dergisi, 38, $150-164$.

K1lıçer, K. (2011). Bilgisayar ve öğretim teknolojileri ĕgitimi öğretmen adaylarının bireysel yenilikçilik profilleri. Doktora Tezi, Anadolu Üniversitesi, Eskişehir.

K1lıç, H. ve Ayvaz Tuncel, Z. (2014). İlköğretim branş öğretmenlerinin bireysel yenilikçilik düzeyleri ve yaşam boyu öğrenme eğilimleri. Uluslararası Eğitim Programları ve Öğretim Çalışmalarl Dergisi, 4(7), 25-37.

Köroğlu, A. Y. (2014). Okul öncesi öğretmenlerinin ve ögretmen adaylarının bilişim teknolojileri özyeterlik algıları, teknolojik araç gereç kullanım tutumları ve bireysel yenilikçilik düzeylerinin incelenmesi. Yüksek Lisans Tezi, Gazi Üniversitesi, Ankara.

Lope Pihie, Z. A., Bagheri, A. ve Asimiran, S. (2014). School leadership and innovative principals: implications for enhancing principals' leadership knowledge and practice. Proceedings of the European Conference on Management, Leadership \& Governance, 6 , 162-167.

McGeown, V. (1980). Dimensions of teacher innovativeness. British Educational Research Journal, 6(2), 147-169.

Önen, A. S. ve Koçak, C. (2014). Analysis on reflective thinking tendencies of student teachers according to their individual innovativeness and sociotropic-autonomic personality characteristics. Procedia-Social and Behavioral Sciences, 143, 788-793.

Özçiftçi, M. (2014). Sinıf öğretmenlerinin yaşam boyu öğrenme eğilimleri ile eğitim teknolojisi standartlarına yönelik özyeterliklerinin ilişkisi. Yüksek Lisans Tezi, Amasya Üniversitesi, Amasya.

Rogers, M. E. (1995). Diffusion of innovations (Fifth Edition). New York: Free Press.

Scott, S. G. ve Bruce, R. A. (1994). Determinants of innovative behavior: a path model of individual innovation in the workplace. Academy of Management Journal, 37(3), 580607.

Şahin, Ç. ve Arcagök, S. (2014). Öğretmenlerin yaşam boyu öğrenme yeterlikleri düzeyinin çeşitli değişkenler açısından incelenmesi. Sosyal Bilimler Dergisi, 7(16), 394-417.

Uzunboylu, H., \& Hürsen, Ç. (2011). Yaşam boyu öğrenme yeterlik ölçeği (YBÖYÖ): Geçerlik ve güvenirlik çalışması. Hacettepe Üniversitesi Eğitim Fakültesi Dergisi, 41, 449-460. 
Yılmaz Öztürk, Z. ve Summak, M. S. (2014). İlköğretim okulu öğretmenlerinin bireysel yenilikçiliklerinin incelenmesi. International Journal of Science Culture and Sport, SI(1), 844-853.

Žnidaršič, J. ve Jereb, E. (2011). Innovations and lifelong learning in sustainable organization. Organizacija, 44(6), 185-194. 


\title{
Investigation of Lifelong Learning Trends and Individual Innovativeness level of Education Administrators ${ }^{1}$
}

\begin{tabular}{|c|c|c|c|}
\hline $\begin{array}{l}\text { ARTICLE TYPE } \\
\text { Research Article }\end{array}$ & $\begin{array}{c}\text { Received Date } \\
01.02 .2018 \\
\end{array}$ & $\begin{array}{c}\text { Accepted Date } \\
03.15 .2018 \\
\end{array}$ & $\begin{array}{c}\text { Online First Date } \\
03.16 .2018 \\
\end{array}$ \\
\hline \multicolumn{4}{|c|}{$\begin{array}{c}\text { Ramazan Yılmaz iD } \\
\text { Bartın University }\end{array}$} \\
\hline & $\begin{array}{l}\text { Yaşar Mu } \\
\text { Ministry of } \mathrm{N}\end{array}$ & $\begin{array}{l}\text { Beşkaya }{ }^{3} \\
\text { onal Education }\end{array}$ & \\
\hline
\end{tabular}

\begin{abstract}
The aim of this research is to examine the relationship between the individual innovativeness level of education administrators and their lifelong learning tendencies, by examining the lifelong learning tendencies of individual education administrators and individual innovativeness levels according to various variables (gender, management experience, age and education level). Survey method was used for this research. The participants of the research consist of 164 education administrators who worked in Bartın province in 2015-2016 education year and voluntarily participated in the research. The data collection tools used in the study were personal information form, lifelong learning tendencies scale and individual innovativeness scale. As a result of the research; it is concluded that there is a positive, moderate and meaningful relationship between the lifelong learning tendencies of education administrators and individual innovativeness levels. Various suggestions have been made to researchers, practitioners and decision makers as a result of the findings obtained from the research.
\end{abstract}

Keywords: Educational administrators, lifelong learning tendency, individual innovativeness

\footnotetext{
${ }^{1}$ This research was supported by the Scientific Research Projects Commission of Bartın University, Turkey (Project No: 2016-SOS-CY-006).

${ }^{2}$ Corresponding Author: Asist. Prof. Dr., Faculty of Education, Department of Computer Education \& Instructional Technology, Bartın/Turkey. E-mail: ramazanyilmaz067@gmail.com; https://orcid.org/0000-0002-2041-1750

${ }^{3}$ Teacher, Bartın/Turkey. E-mail: beskaya79@hotmail.com; https://orcid.org/0000-0002-8738-8372
} 


\section{Summary}

The aim of this research is to examine the relationship between the individual innovativeness level of education administrators and their lifelong learning tendencies, by examining the lifelong learning tendencies of individual education administrators and individual innovativeness levels according to various variables (gender, management experience, age and education level). Survey method was used for this research. The participants of the research consist of 164 education administrators who worked in Bartın province in 2015-2016 education year and voluntarily participated in the research. The survey used for the research data was developed by the researcher to obtain various demographic information of the participants and used "Lifelong Learning Tendencies Scale" developed by Diker Coşkun (2009) in order to determine the lifelong learning tendencies of the education administrators and "Individual Innovativeness Scale" adapted into Turkish by Kiliçer and Odabaş1 (2010) in order to determine the individual innovativeness levels of the educational administrators. Analysis of the research data were made with SPSS package software. T-test and ANOVA from parametric tests were used for descriptive statistics (arithmetic mean, standard deviation), and Mann-Whitney $U$ test and Kruskal-Wallis H test for non-parametric tests in the analysis of data. Spearman's rho correlation analysis was used to determine the relationship between the two scales.

As a result of the research; it is seen that the lifelong learning tendencies of the education administrators participating in the research are above the mid-scale and the individual innovativeness levels are in the questioning category. It is concluded that there is a positive, moderate and meaningful relationship between the lifelong learning tendencies of education administrators and individual innovativeness levels. Lifelong learning tendencies of education administrators showed significant differences according to gender and lifelong learning tendencies of women education administrators were found to be higher. It has been found that the lifelong learning tendencies of the education administrators do not show any significant difference according to the managerial experience.

Educational administrators' lifelong learning tendencies were not significantly different by age. It has been observed that there is a significant difference in the lifelong learning tendencies of the education administrators compared to the education levels and that the lifelong learning tendencies of the graduate educators are higher.

It was seen that there was no significant difference between the levels of individual innovativeness of education administrators by gender. It was observed that the individual innovativeness level was significantly different from the level of managerial experience of education administrators and that the individual innovation level scores increased as managerial experience increased. It has been seen that there is no significant difference in the level of individual innovativeness of education administrators according to age. According to the education levels, there was no significant difference between the individual innovation scores of the educational administrators. 